\title{
'Rice-grain' or 'cigar-shaped' calcification: radiological clue and minor criteria for neurocysticercosis
}

\author{
Naveen Kumar, Deepak Sundriyal, Paawan Wadhawan, Riyaz Charaniya
}

Department of Internal Medicine, P.G.I.M.E.R. \& Dr Ram Manohar Lohia Hospital, New Delhi, Delhi, India

\section{Correspondence to}

Dr Naveen Kumar, docnaveen2605@yahoo.co.in

Accepted 6 June 2014
CrossMark

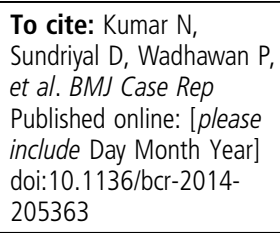

\section{DESCRIPTION}

A 46-year-old man, labourer by occupation, presented with headache for 2 weeks and one episode of generalised tonic-clonic seizures. Neurological examination was normal except for postictal confusion. Non-contrast CT of the brain was carried out which showed multiple, 1-2 mm calcified granuloma, some showing perilesional oedema in the frontal, parietal and occipital lobes, more on the left hemisphere. The lesions were suggestive of neurocysticercosis (NCC). As the patient could not afford an MRI brain, for supportive evidence we examined the fundus which did not show cysticerci, but the routine chest radiograph showed typical rice-grain-shaped calcification in the chest wall muscles (figure 1). Examination of the patient did not have any subcutaneous palpable nodule, tenderness or hypertrophy of muscle. Radiograph of the thigh and forearm were ordered which showed similar lesions (figures 2 and 3). The patient was started on albendazole, phenytoin and a short course of steroid. At the end of a 3-week follow-up, he was seizure free and headache free. Albendazole was stopped and phenytoin was continued.

NCC is the most common parasitic infestation of the central nervous system and the cause of acquired seizures in developing countries. Seizure

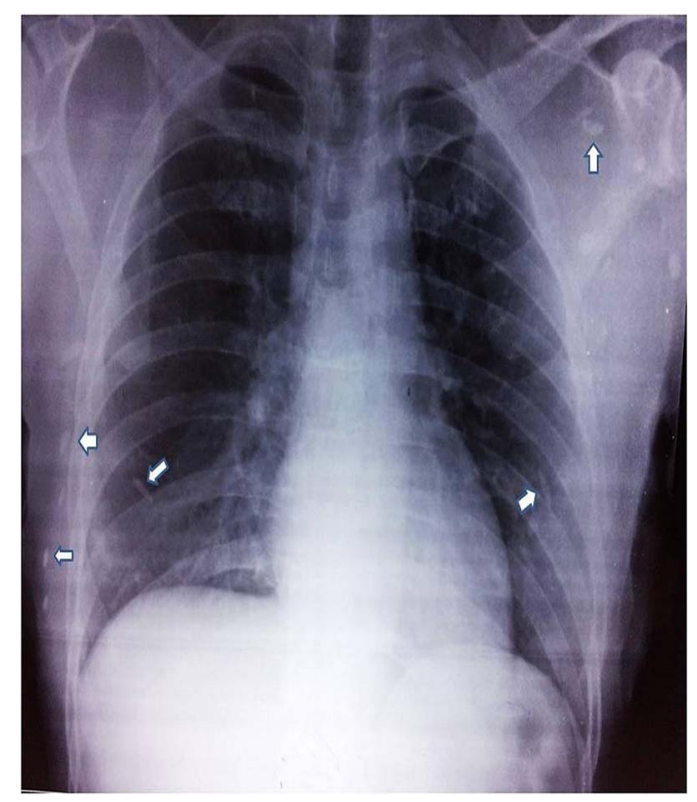

Figure 1 Chest radiograph showing typical 'rice-grain' or 'cigar-shaped' calcified lesions in the muscles of chest wall (white arrow).

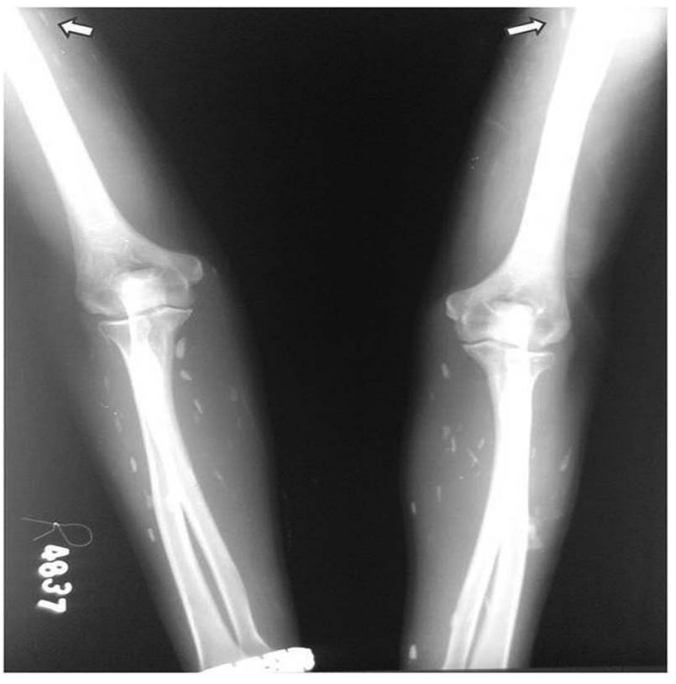

Figure 2 Radiograph of both the upper limbs shows multiple 'rice-grain'-shaped ovoid calcification arranged along the long axis of the muscle (white arrow). They are dead cyst.

as manifestation occurs in $50-80 \%$ patients. ${ }^{1}$ Ring-enhancing lesion poses diagnostic challenge particularly in tropical areas as NCC and tuberculoma have similar presentation and radiological features. Many of these patients do not have typical radiological lesion or positive serology to fulfil the diagnostic criteria of Del Brutto et al. ${ }^{2}$ In such circumstances radiograph of soft tissues showing rice-

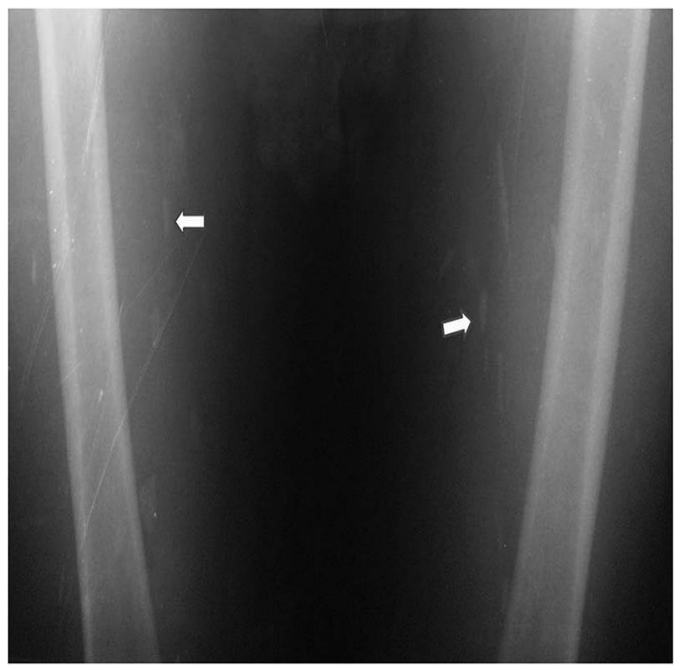

Figure 3 Radiograph of both thighs showing 'cigar-shaped' muscular calcification arranged parallel to the long axis of the muscle (white arrow). 


\section{Learning points}

- Demonstration of rice-grain clacification on plain radiograph is a minor diagnostic criterion for neurocysticercosis (NCC).

- Their presence support NCC as the cause of ring-enhancing lesions in brain imaging.

- Radiographs of soft tissues are cheap and widely available supportive evidence, but often overlooked. They are especially important when patient cannot afford expensive investigations like an MRI.

grain calcification not only differentiates it from tuberculoma but also forms a minor diagnostic criteria. ${ }^{2}$ Rice-grain or cigarshaped calcification is ovoid-shaped calcification in soft tissues, particularly muscles. It is characteristic of infection with Taenia solium (cysticercosis). When cysticerci larva spread from the intestine, they get deposited in soft tissues and skeletal muscles of upper and lower extremities, and in the abdominal and chest wall. Later inflammatory response of the host kills larva, which get calcified and deposited along the long axis of the muscle. Usually they are multiple and can present with hypertrophy of muscles, maylgia and palpable nodules. As they are asymptomatic, surgical excision is only indicated for histological examination.

Contributors NK, DS and PW participated in the diagnosis and management of the patient, concept of paper, acquiring data, drafting paper, revision of draft andin the final approval. RC participated in the diagnosis and management of patient, acquiring data, drafting paper and in the final approval.

Competing interests None.

Patient consent Obtained.

Provenance and peer review Not commissioned; externally peer reviewed.

\section{REFERENCES}

1 Mahajan SK, Machhan PC, Sood BR, et al. Neurocysticercosis presenting as psychosis. J Assoc Physicains India 2004;52:663-5.

2 Del Brutto OH, Rajshekhar V, White AC Jr, et al. Proposed diagnostic criteria for neurocysticercosis. Neurology 2001;57:177-83.

Copyright 2014 BMJ Publishing Group. All rights reserved. For permission to reuse any of this content visit http://group.bmj.com/group/rights-licensing/permissions.

BMJ Case Report Fellows may re-use this article for personal use and teaching without any further permission.

Become a Fellow of BMJ Case Reports today and you can:

- Submit as many cases as you like

- Enjoy fast sympathetic peer review and rapid publication of accepted articles

- Access all the published articles

- Re-use any of the published material for personal use and teaching without further permission

For information on Institutional Fellowships contact consortiasales@bmjgroup.com

Visit casereports.bmj.com for more articles like this and to become a Fellow 